\title{
THE JOURNAL OF PHYSIOLOGY
}

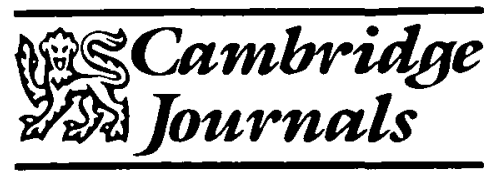

\section{Published for the Physiological Society}

Chairman of the Editorial Board:

\section{A. V. Edwards, University of Cambridge}

This internationally respected journal publishes high quality papers representing original experimental work in three areas: general physiology, mammalian physiology, and human physiology. Each hardbound monthly volume of The Journal of Physiology is concerned with respiration, circulation, excretion, reproduction, digestion, homeostasis, and particularly neurophysiology and muscular contraction. Abstracts of scientific meetings of the Physiological Society, which are accepted by the members present at those meetings, are also published. A Cumulative Subject and Author Index is produced triennially and an Annual Index is produced in the intervening years.

THE JOURNAL OF PHYSIOLOGY

$$
\text { ..n........ }
$$

THE PHYSIOLOGICAL SOCHET

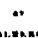

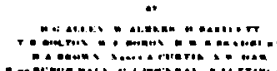

ren.

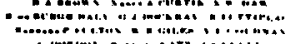

- A

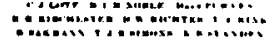

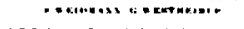

(n)

CAMOMIIMER UKIVERSITY RKRSA

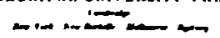

\section{Selected papers}

Co-ordinated variations in chloride-dependent potassium transport and cell water in normal human erythrocytes, G. W. Stewart

Influence of right atrial stretch and atrial natriuretic factor on rate intestinal fluid content, $S$. Kaufman \& $E$. Monckton

Outward rectification of inhibitory postsynaptic currents in cultured rat hippocampal neurons, J. L. Barker \& $N$. L. Harrison

Review Lecture: Capillary permeability and how it may change, C. C. Michel

The Journal of Physiology (ISSN 0022-3751) is published monthly in 1989 . Subscription to volumes 408 419: $\$ 1200.00$ per year; $\$ 106.00$ per volume.

Back Volumes: $254-407$ (1976-1988) \$115.00 each.

Journals Department

Cambridge University Press 


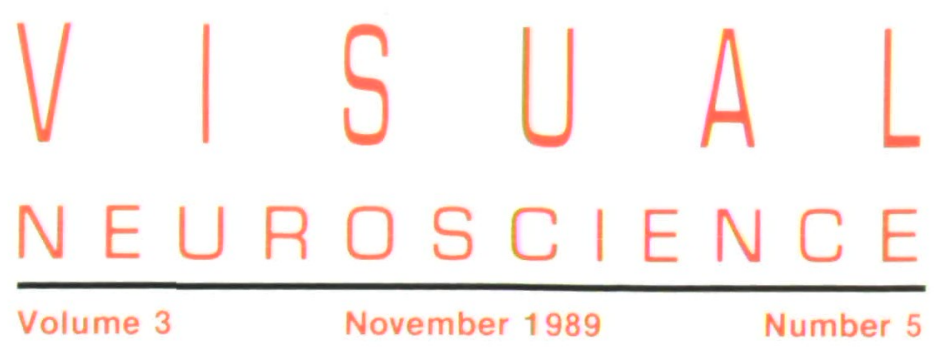

\section{CONTENTS}

DiAnNA A. REDBURN AND Cheryl K. Mitcheli

S.R. SHaW AND D. MOORE

Alan R. Adolph

Christine Blazynski

R. RANNEY MIZE AND Susan Hockfield

Y. TADMOR AND D.J. TOLHURST

RETO WEILER AND Alexander K. Ball

Luiz R.G. BRitTo, DANIA E. HAMASSAKI, KENT T. KEYSER, AND HaRvey J. Karten

LUIZ R.G. BRITTO, KENT T. KEYSER, Dania E. Hamassaki, TORU SHIMIZU, AND Harvey J. Karten

L.C.L. Silveira, E.S. YAMADA, AND C.W. Picanço-Diniz
391

405

411

425

433

445

455

463

477

\section{Research Articles}

Darkness stimulates rapid synthesis and release of melatonin in rat retina

Evolutionary remodeling in a visual system through extensive changes in the synaptic connectivity of homologous neurons

Pharmacological actions of peptides and indoleamines on turtle cell retinal ganglion cells

5 Displaced cholinergic, GABAergic amacrine cells in the rabbit retina also contain adenosine

3 Cat-301 antibody selectively labels neurons in the Y-innervated laminae of the cat superior colliculus

The effect of threshold on the relationship between the receptivefield profile and the spatial-frequency tuning curve in simple cells of the cat's striate cortex

Enkephalinergic modulation of the dopamine system in the turtle retina

Neurotransmitters, receptors, and neuropeptides in the accessory optic system: An immunohistochemical survey in the pigeon (Columba livia)

\section{Short Communications}

Chemically specific retinal ganglion cells collateralize to the pars ventralis of the lateral geniculate nucleus and optic tectum in the pigeon (Columba livia)

Displaced horizontal cells and biplexiform horizontal cells in the mammalian retina

Detailed Information for Contributors

The Humane Care and Use of Animals 